\title{
Um Estudo das Ações Discentes em Sala de Aula de um Campus do Instituto Federal do Paraná
}

\section{A study of student actions in the classroom of a campus of a Federal Institute of Paraná}

\author{
Marily Aparecida Benicio \\ Sergio de Mello Arruda \\ Marinez Meneghello Passos \\ Brasil \\ Brasil \\ Brasil
}

Esta investigação apresenta uma proposta de análise das ações discentes em sala de aula para as disciplinas de Física, Matemática e Química de um curso de Ensino Médio e Técnico Integrado do estado do Paraná. A investigação tem como suporte teórico o conceito de aprendizagem de Illeris; os estudos de Charlot a respeito da relação com o saber e o aprender como uma prática do saber. A questão de pesquisa que norteou o movimento investigativo foi: Quais são as categorias de ações discentes em aulas de Física, Matemática e Química? Os procedimentos metodológicos adotados fazem parte do aporte teórico da Análise Textual Discursiva. Os dados analisados são provenientes da gravação de aulas e de notas de campo. Entre os resultados evidenciados, destacamos sete categorias emergentes de ações discentes que respondem à questão de pesquisa: Organiza, Interage com a Professora, Interage com os Colegas, Pratica, Espera, Dispersa e Outras Ações.

Palavras-chave: Ação discente; Aprendizagem científica; Relação com o saber.

This research presents a proposal of analysis of student actions in the classroom for the disciplines of Physics, Mathematics and Chemistry of a course of High School and Integrated Technician of the State of Paraná, Brazil. The research has as theoretical support the concept of learning of Illeris; Charlot's studies on the relationship with knowledge and learning as a practice of knowledge. The research question that guided the investigative movement was: What are the categories of student actions in physics, mathematics and chemistry classes? The methodological procedures adopted are part of the theoretical contribution of the Discursive Textual Analysis. The data analyzed come from the recording of lessons and field notes. Among the evidenced results, we highlight seven emerging categories of student actions that answer the research question: Organize, Interact with the Teacher, Interact with Colleagues, Practice, Wait, Disperse, and Other Actions.

Keywords: Student action; Scientific learning; Relationship with knowledge. 


\section{Introdução}

A presente investigação faz parte de um programa de pesquisa, em que se estuda a temática ações docentes desde 2010. Na literatura é possível encontrar inúmeras pesquisas a respeito das atividades docente, tais como: o desenvolvimento do conhecimento profissional, Schön (1992); os conceitos de gestão de classe e gestão da matéria, Gauthier et al. (2013); a transmissão da matéria e a gestão da interação com os alunos, Tardif (2014); entre outros. Fundamentados nesses e outros estudos a respeito da prática docente e em conjunto com a temática da relação com o saber disposta em Charlot (2000), foi elaborada uma proposta para a análise das ações docentes em suas relações de ensino e de aprendizagem em sala de aula (Arruda, Lima, \& Passos, 2011). Os avanços obtidos a partir dessa elaboração, permitiram ampliar as investigações para além da ação do docente (Andrade, 2016; Andrade, Arruda, \& Passos, 2018; Carvalho, Arruda, \& Passos, 2018; Dias, Arruda, Oliveira, \& Passos, 2017), envolvendo outros sujeitos integrantes do universo escolar e suas ações, tais como: as ações de professores supervisores (Carvalho, Arruda, \& Passos, 2018); as ações discentes (Benicio, 2018; Arruda, Benicio, \& Passos, 2017); as possíveis conexões entre as ações discentes e docentes (Dias, 2018).

O presente artigo versa a respeito da prática discente em sala de aula, ou seja, as ações discentes. Ao lançarmos o olhar para o agir do aluno no ambiente escolar, interessanos levantar as diferentes ações realizadas e suas implicações para a aprendizagem discente. Os referenciais que sustentaram a investigação foram Illeris (2013), Charlot (2000), Leontiev (2014) e Weber (2012). O primeiro apresenta uma definição para a aprendizagem humana, em que diferentes áreas e condições foram reunidas para elaborar um modelo abrangente. O segundo teórico apresenta a teoria da relação com o saber, que trata de uma sociologia do sujeito. Charlot (2000) também define a aprendizagem como uma atividade intelectual, associada à prática do saber, que considera os conceitos de atividade e de ação, fundamentados, respectivamente, nos estudos dos dois últimos teóricos supracitados. Sobre eles, discorremos na próxima seção.

O caminho metodológico adotado para a realização desta pesquisa foi a abordagem qualitativa, pelo caráter descritivo e interpretativo dos dados. Dentro dessa abordagem optamos pela Análise Textual Discursiva (ATD) proposta por Moraes e Galiazzi (2011), a qual, diante de seus procedimentos analíticos, permitiu-nos atingir o objetivo de elaborar categorias de ações discentes em aulas de Física, Matemática e Química. Dedicamos a segunda seção após esta introdutória para apresentar, inicialmente, a ATD, descrever o contexto de pesquisa e trazer detalhes relativos aos movimentos organizacionais dos dados e de suas interpretações.

Em seguida, elaboramos uma seção com a análise dos dados ${ }^{1}$, que teve seus movimentos iniciais pautados na descrição das aulas elegidas para estudo. Essas informações descritivas e interpretativas foram organizadas em sete categorias

1 Os dados em sua completude podem ser acessados em Benicio (2018). 
emergentes, relacionadas às ações discentes observadas no contexto investigado: Organiza $^{2}$, Interage com a Professora, Interage com os Colegas, Pratica, Espera, Dispersa e Outras Ações.

Por fim, tecemos nossas considerações sobre o que os dados nos apontam e as conclusões que este fenômeno investigado nos proporcionou.

\section{Fundamentação Teórica}

São inúmeros os conceitos de aprendizagem que encontramos na literatura, mesmo limitando-nos ao que foi produzido do século XIX até os dias de hoje. Para o desenvolvimento de nossa pesquisa pautamo-nos no que Illeris (2013) apresenta no livro Teorias contemporâneas de aprendizagem, mais especificamente em um modelo que, segundo o Autor, sintetiza a compreensão geral e atual deste campo de pesquisa.

A definição para a aprendizagem apresentada por Illeris (2013) é uma formulação ampla que contempla diversos processos e condições relacionadas a ela. A aprendizagem é definida como "qualquer processo que, em organismos vivos, leve a mudança permanente em capacidades e que não se deva unicamente ao amadurecimento biológico ou ao envelhecimento" (Illeris, 2013, p. 3). Tal modelo abrange dois processos diferentes, mas integrados entre si, como pode ser observado na Figura 1.

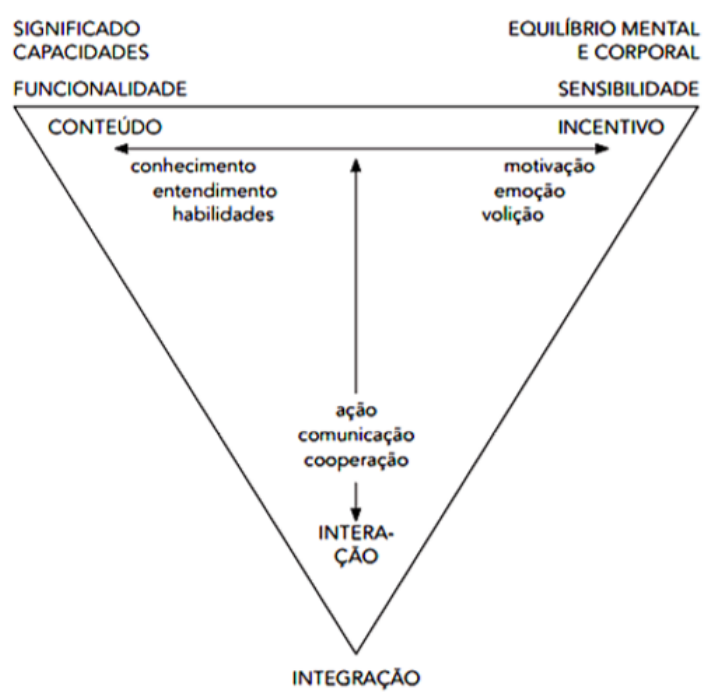

Figura 1. As três dimensões da aprendizagem

Fonte: Illeris (2013, p. 19)

O primeiro é o processo externo de interação entre o sujeito e o ambiente. $\mathrm{O}$ segundo é o processo psicológico interno de elaboração e aquisição, o qual envolve duas funções psicológicas: “a função de administrar o conteúdo de aprendizagem e a função

2 Os verbos que compõem as sete categorias evidenciadas estão no presente do indicativo na terceira pessoa do singular. Optamos por essa forma de apresentação, pois para nós era a que melhor representava o que os alunos faziam na sala de aula no momento em que coletamos os dados. Ele (aluno): organiza, interage, pratica, espera, dispersa. 
de incentivo e de prover a energia necessária que move o processo" (Illeris, 2013, p. 17). Em conjunto eles formam uma tríade, cujos elementos são conteúdo, incentivo e interação, também chamados de dimensões.

Frente ao exposto a respeito da aprendizagem é perceptível que ela compreenda três aspectos. Um deles é o epistêmico, uma vez que há a elaboração e aquisição de conteúdo específico. A segunda faceta é a pessoal, a qual envolve a emoção do sujeito como incentivo à aprendizagem, as experiências pessoais atribuem sentido ao que é aprendido, além de que o aprender colabora para a construção do eu. Outra face é a social, presente na interação com o ambiente externo ou na necessidade de participar de práticas e comunidades científicas.

A teoria da relação com o saber proposta por Charlot (2000), assim como por Illeris (2013), apresenta o aprender de maneira ampla, no sentido que considera aspectos tanto da Sociologia, como da Psicologia e da Antropologia. Para Charlot (2000), aprender é uma necessidade humana e ocorre quando o sujeito em sua relação com o mundo, com o outro e consigo, envolve-se em uma prática do saber.

Segundo Charlot (2000), o aluno é um sujeito confrontado com a necessidade de aprender em um mundo já estabelecido antes dele, e que tem presente conhecimentos diversos. Para o autor o sujeito é:

- um ser humano, aberto a um mundo que não se reduz ao aqui e agora, portador de desejos [grifo nosso], movido por esses desejos, em relação com outros seres humanos, eles também sujeitos;

- um ser social [grifo nosso], que nasce e cresce em uma família (ou em um substituto da família) que ocupa uma posição em um espaço social, que está inscrito em relações sociais;

- um ser singular [grifo nosso], exemplar único da espécie humana, que tem uma história, interpreta o mundo, dá um sentido a esse mundo, à posição que ocupa nele, às suas relações com os outros, à sua própria história, à sua singularidade (Charlot, 2000, p. 33).

Charlot argumenta que o homem não é como os outros animais na natureza, que nascem acabados. Ao contrário, o homem nasce em um mundo preexistente já estruturado ao longo da história da humanidade devendo tornar-se homem, o que ocorre por meio da educação. Em sua incompletude o homem procura aprender, apropriar-se do legado histórico-sociocultural que foi criado ao longo do tempo pela espécie humana:

Nascer é penetrar nessa condição humana. Entrar em uma história, a história singular de um sujeito inscrita na história maior da espécie humana. Entrar em um conjunto de relações e interações com outros homens. Entrar em um mundo onde ocupa um lugar (inclusive, social) e onde será necessário exercer uma atividade (Charlot, 2000, p. 53).

A aprendizagem, para Charlot (2005), é um processo que se torna possível ao sujeito quando este se envolve em uma prática do saber. Nesse sentido, para que o sujeito 
aprenda é preciso entrar em sistemas de relação com o mundo, com outros e consigo mesmo, envolver-se em atividades práticas, reflexivas e relacionais. O autor descreve alguns tipos de aprendizado, que denomina por figuras do aprender e que sublinhamos na citação a seguir.

Aprender pode ser adquirir um saber[grifo nosso], no sentido estrito da palavra, isto é, um conteúdo intelectual . . . .Mas, aprender pode ser dominar um objeto ou uma atividade [grifo nosso] (atar os cordões dos sapatos, nadar, ler...), ou entrar em formas relacionais [grifo nosso] (cumprimentar uma senhora, seduzir, mentir...) (Charlot, 2000, p. 59).

Para o contexto escolar, Charlot (2013) coloca que "quem aprende é o aluno. Se não quiser, recusando-se a entrar na atividade intelectual, não aprenderá, seja qual for o método da professora" (p. 107). É necessária a mobilização do sujeito para o desenvolvimento de ações direcionadas e contextualizadas, com o objetivo de aprender.

Para abordar a questão da atividade, Charlot apresenta a perspectiva de Leontiev (1984, citado em, Charlot, 2013), que a define como "uma série de ações e operações, com um motivo e um objetivo" (p. 143). Leontiev (1978) coloca que necessidade, objeto e motivo são componentes estruturais da atividade e a necessidade é a primeira condição. O que distingue uma atividade de outra é seu objeto, e este é o que lhe confere determinada orientação. $\mathrm{O}$ que impulsiona a atividade é o motivo, ele é determinado quando a necessidade, possível de ser satisfeita, encontra o seu objeto.

A atividade também não pode existir senão pelas ações. Com a intenção de atingir um objetivo geral, é desencadeada uma série de ações que estão subordinadas a objetivos menores. A respeito disso, Leontiev (2014) escreve que "os componentes básicos de atividades humanas separadas são as ações que as realizam. Consideramos ação o processo que corresponde à noção do resultado que deve ser atingido, isto é, o processo que obedece a um objetivo consciente" (p. 184).

Atividade humana existe como ação ou uma corrente de ações. [...] Quando consideramos o desdobramento de um processo específico - externo ou interno - a partir do ângulo do motivo, aparece como atividade humana, mas quando consideramos como um processo orientado a um objetivo, aparece como uma ação ou um sistema, uma corrente de ações (Leontiev, 2014, p. 190).

Ao tomarmos o conceito de ação como primordial em nossa investigação, não podemos deixar de citar Weber (2012), quando discute a tipologia clássica da ação e apresenta um estudo sobre a ação social. O autor conceitua a ação como "um comportamento humano (tanto faz tratar-se de um fazer externo ou interno, de omitir ou permitir), sempre na medida em que o agente ou os agentes o relacionem com um sentido subjetivo" (Weber, 2012, p. 3). Ele também remete à ação social "quando o seu sentido visado pelo agente ou os agentes, se refere ao comportamento de outros, orientando-se por este em seu curso" (Weber, 2012, p. 3).

Nesse sentido, no aprender como prática do saber, o sujeito depara-se com a incumbência de desenvolver atividades e ações, conforme se apresentam as necessidades, 
os motivos e os objetivos em um contexto específico e conforme se dispõem de condições internas e externas para realizá-las. Na relação com o saber, mais amplamente com o aprender, conforme já mencionado, a relação epistêmica apresenta três formas distintas de se aprender. Em cada uma dessas três figuras do aprender há uma atividade de natureza diferente, como a "constituição de um universo de saberes-objeto, ação no mundo, regulação da relação com os outros e consigo" (Charlot, 2000, p. 71). Em cada uma dessas situações existe um sujeito consciente que realiza essas atividades e controla suas próprias ações.

Após esta exposição resumida do que assumimos por aprender, saber, atividade e ação, juntamente com os teóricos que as apresentam, damos continuidade ao artigo esclarecendo a respeito dos procedimentos metodológicos selecionados para o desenvolvimento desta investigação e descrevendo alguns detalhes da situação de pesquisa.

\section{Procedimentos Metodológicos e a Situação Investigada}

A escolha pela ATD deu-se pelo fato de ser uma abordagem organizacional e metodológica dos dados utilizada em pesquisas que trabalham com informações na forma textual e para a elaboração de novos conhecimentos a respeito de um fenômeno ou discurso. Por meio da ATD e com o propósito de aprofundar a compreensão da ação do estudante e das suas relações construídas em sala de aula, procurou-se categorizar as ações discentes em aulas de Física, Matemática e Química. Segundo Moraes e Galiazzi (2011), "a análise textual discursiva pode ser entendida como o processo de desconstrução, seguido de reconstrução, de um conjunto de materiais linguísticos e discursivos, produzindo-se a partir disso novos conhecimentos (sobre os fenômenos e discursos investigados)" (p. 112).

Os materiais submetidos à análise, ou seja, o nosso corpus ${ }^{3}$ investigativo foi composto por registros escritos na forma de notas de campo elaborados no decorrer da observação das aulas e as transcrições de gravações em áudio e vídeo, também dessas mesmas aulas. A análise consistiu em descrever e interpretar as informações contidas nesses documentos. Assim como indica a própria ATD, a interpretação realizada foi para além do dito, atingindo significados que, por vezes, nem os sujeitos analisados tinham consciência.

Destacamos ainda que a ATD pode ser entendida como um processo autoorganizado de compreensão e de construção de novos conhecimentos que emergem a partir do ciclo criado por três etapas: desmontagem do texto; estabelecimento de relações; captação do novo emergente.

A primeira delas é denominada por Moraes e Galiazzi (2011) de unitarização, essa etapa "é parte do esforço de construir significados a partir de um conjunto de textos, entendendo que sempre há mais sentidos do que uma leitura possibilita elaborar" (p. 49).

3 O conjunto dos documentos tidos em conta para serem submetidos aos procedimentos analíticos (Bardin, 2011, p. 126). 
A unitarização encontra sua finalidade quando as unidades permitem o direcionamento para a construção das categorias. Na presente investigação esta etapa compreendeu a desconstrução do corpus de pesquisa. As notas de campo foram fragmentadas em unidades de contexto (denominação assumida por nós no desenvolvimento desta pesquisa) ou unidades de análise (Moraes, \& Galiazzi, 2011), as quais continham um verbo que representavam as descrições das ações discentes observadas em sala de aula.

A categorização, segunda etapa, corresponde à organização e classificação das unidades de contexto, que permite expressar novas compreensões do fenômeno em estudo. A categorização pode assumir o papel de processo de classificação ou de processo de análise. Por meio da categorização foi possível organizar as unidades obtidas na unitarização considerando o verbo utilizado que representava a ação discente e o contexto em que este foi utilizado. Nesse sentido, um mesmo verbo pode ser alocado em diferentes categorias devido a distinção do contexto em que ele foi empregado. A categorização permitiu agrupar estas unidades a partir de suas similaridades dentro do fenômeno investigativo.

A terceira etapa diz respeito à captação do novo emergente, momentos em que se buscam expressar as compreensões atingidas. Isso significa que nesta fase se constrói os metatextos, ou seja, elabora-se uma produção escrita em que os fatos analisados podem adquirir novos sentidos, promovendo novas compreensões do fenômeno investigado. A pesquisa aqui apresentada permitiu a elaboração de metatextos em dois movimentos interpretativos. O primeiro no processo de construção das descrições das categorias emergentes da observação da situação investigada. O segundo se constituiu na escrita do novo emergente apresentado ao longo da seção de análise de dados, em que se apresentam os sentidos, nuances e compreensões obtidos a respeito da situação de estudo.

A coleta de dados para esta pesquisa, cujos resultados trazemos neste artigo, foi realizada no ano de 2016, período em que acompanhamos no primeiro bimestre uma turma de terceiro ano do Ensino Médio e Técnico em Automação Industrial em um câmpus do Instituto Federal do Paraná. A turma era composta por trinta e um alunos, todos aceitaram participar da investigação, para tal fim, foi solicitada a entrega do termo de consentimento livre e esclarecido assinado pelo responsável legal de cada um dos estudantes.

Os dados coletados foram descritivos e organizados em unidades de contexto que descrevem aquilo que os alunos faziam nas salas de aula e que foi capturado pelas gravações em vídeo e elencadas nas notas de campo. Ressalta-se que as ações foram levantadas mediante a observação dos estudantes in locus. Sabe-se que questões culturais e socioeconômicas podem interferir no comportamento dos sujeitos de pesquisa e nas motivações quanto ao seu agir. Contudo foram consideradas, durante a coleta de dados, apenas as ações ocorridas e observáveis, os motivos que desencadearam tais ações foram inferidos a partir do contexto da sala de aula e das relações ali estabelecidas, não sendo realizado para o momento o aprofundamento em questões de outra natureza. 
$\mathrm{Na}$ intenção de preservar a identidade dos sujeitos envolvidos na pesquisa, os alunos foram designados pela letra A. Como a turma, em questão, era composta por trinta e um alunos, os sujeitos foram codificados por A1, A2, A3, ..., A31. No processo de codificação para as professoras ${ }^{4}$ empregou-se a letra $\mathrm{P}$ em conjunto com a primeira letra da disciplina que lecionavam. Com isso, as siglas PF, PM e PQ referem-se às professoras das disciplinas de Física, Matemática e Química, respectivamente.

Os resultados que trazemos neste artigo fazem parte de um conjunto de duas aulas geminadas referente a cada disciplina. Isto é, para a realização da análise de dados que aqui apresentamos realizamos um estudo nestas seis aulas, que julgamos representativas da atuação de cada uma das professoras durante o bimestre em que foram observadas. Essa representatividade se justifica pela semelhança em sua estrutura, planejamento e execução com as demais aulas que decorreram no bimestre para cada disciplina.

Tendo em mãos esse corpus e a metodologia de análise assumida neste processo investigativo, foi possível elaborar categorias de ações discentes em sala de aula, o que vai ao encontro do que nos propusemos responder: Quais são as categorias de ações discentes em aulas de Física, Matemática e Química? Informações e esclarecimentos sobre esses resultados obtidos estão descritos na próxima seção.

\section{Análise dos Dados}

Esta seção foi organizada da seguinte forma: primeiramente, trazemos uma breve exposição das características observadas em cada aula analisada; em seguida, descrevemos as categorias de ações que emergiram durante a interpretação dos registros presentes no corpus; por fim, realizamos o enquadramento das unidades de contexto de acordo com as categorias de ação evidenciadas, o que nos permite uma visualização dessa distribuição do que os alunos faziam no decorrer de cada uma das disciplinas e uma ágil comparação entre esses enquadramentos na forma de diagramas.

\section{As Aulas Analisadas: Alguns Destaques}

As aulas de Matemática elencadas para análise ocorreram no início do primeiro bimestre de 2016. Destacam-se dois momentos principais da aula, o momento de correção de exercícios e o de exposição de novos conteúdos. No primeiro momento a professora corrigiu os exercícios, sobre o conteúdo: distância entre dois pontos, indicados como dever de casa na aula anterior. No segundo momento PM introduziu, de forma expositiva, o conceito de equação de reta, abordando as formas de determinar uma reta e sua equação. As aulas de Matemática observadas caracterizaram-se por sua formalidade, tendo como centro de atenção a professora, que solicitava constantemente a manutenção da ordem na sala aos alunos. Ela (PM) posicionou-se de uma maneira séria e organizada, os alunos corresponderam à forma de agir da professora. A maioria

4 Naquela ocasião todos os docentes das disciplinas investigadas - Física, Matemática e Química - eram do sexo feminino. Por isso utilizaremos sempre a denominação professoras. 
dos alunos chegou no horário e cumpriu com os acordos ${ }^{5}$ estabelecidos entre professor e aluno.

Durante a observação percebeu-se que ocorreram conversas dispersivas em menor quantidade e intensidade (comparando-se com as aulas observadas das demais disciplinas). Os alunos permaneciam sentados e levantavam-se somente quando se dirigiam à professora em busca de permissão para sair da sala. A interação entre professor e aluno foi menor que nas outras disciplinas observadas. Houve poucas perguntas realizadas pelos alunos e grande parte da interação aconteceu devido às perguntas que a própria professora realizava.

As aulas de Física escolhidas para análise aconteceram no início do primeiro bimestre. $\mathrm{O}$ assunto das aulas foi Lei de Coulomb, iniciado de forma conceitual em uma aula anterior, e reapresentado na aula seguinte com a formalização do conceito mediante a linguagem matemática. PF estruturou sua aula, de igual maneira ao ocorrido nas aulas de Matemática, em dois momentos, o primeiro expositivo, utilizando slides como recurso, e o segundo momento focando na apresentação de exercícios intercalados com a correção realizada por ela na lousa.

Nas aulas de Física podemos destacar que o foco se deslocou para os alunos, diferentemente da aula de Matemática. A professora PF organizou as aulas de modo que os alunos participassem e se envolvessem com as discussões e com a realização das atividades propostas, o que nos leva a adjetivá-las por um estilo de aula flexível e descontraído. Os alunos de forma geral eram respeitosos com a professora e interessados no conteúdo exposto, procurando realizar as atividades propostas e participar das discussões. Por outro lado, eles sutilmente buscavam formas de atrasar a aula e o andamento das atividades. Apesar disso, quando a professora tomava a palavra para explicar o conteúdo programático, os alunos colaboravam com o momento da aula prestando atenção, ou, simplesmente, permanecendo em silêncio.

A relação entre professora e aluno foi marcada pela proximidade. Os alunos interagiam com a professora, durante as discussões, buscando entender os conceitos abordados por meio de perguntas e comparações. As questões levantadas pela professora durante a explicação permitiam aos alunos estruturar o raciocínio e fomentavam suas reflexões a respeito do conteúdo, por conseguinte, eles permitiam-se arriscar em suas respostas.

As aulas de Química selecionadas para a investigação ocorreram ao fim do primeiro mês de aula. Assim como nas aulas das demais disciplinas, houve dois momentos distintos: a correção de exercícios e a exposição de um novo conteúdo. A correção foi realizada no início da aula e estava relacionada a uma lista de exercício entregue aos alunos em aulas anteriores e abordava a classificação de cadeias carbônicas. A exposição foi realizada por meio de apresentação de slide, cujo conteúdo trabalhado foi: alcanos.

5 Tais acordos referem-se ao contrato didático discutido coletivamente e firmado entre o docente e os discentes na primeira aula de Matemática do bimestre. Nesse contrato foram estabelecidas algumas regras, incluindo permissões e proibições, que deveriam ser respeitadas pelas partes ao longo do ano letivo. 
As aulas de Química tiveram como atividade principal a exposição de novos conteúdos, tornando a professora o centro das atenções. Com relação ao seu estilo de aula, observamos que teve doses de formalidade e de flexibilidade. Existiram acordos entre professora e alunos e estes eram respeitados; em contraponto com as aulas de Matemática, estas regras eram mais flexíveis. Percebeu-se, ainda, uma forma própria de organização inicial da turma, por parte desta professora, e sua tranquilidade em conduzir as conversas e as brincadeiras, sem a necessidade de chamar a atenção dos alunos (fato muito presente na atuação de PM).

A relação entre PQ e os alunos também refletia esse equilíbrio entre formalidade e flexibilidade. Os alunos agiam com naturalidade e descontração na interação com a professora, eles expunham suas dúvidas, seus medos em relação aos erros que poderiam ocorrer na resolução dos exercícios, suas dificuldades com o processo de aprendizagem do conteúdo químico. PQ, por sua vez, salientava a necessidade de tirarem sempre suas dúvidas e aconselhava-os a estudarem e buscarem maneiras para superarem esses problemas indicados por eles.

Tendo dado ciência a respeito de alguns detalhes dessas aulas analisadas, passamos agora, como já explicitado, a apresentar as sete categorias emergentes: Organiza $(\mathrm{O})$, Interage com a Professora (IP), Interage com os Colegas (IC), Pratica (P), Espera (E), Dispersa (D) e Outras Ações (OA), que codificamos da forma como está entre parênteses, e suas descrições, que para nós significam os critérios utilizados para a alocação daquilo que os alunos realizavam em cada uma delas.

\section{As Categorias Emergentes de Ações Discentes}

Ao interpretarmos o corpus, percebeu-se que nossas unidades de contexto, que eram descrições que representavam aquilo que observávamos que os alunos faziam, poderiam ser organizadas em grupos de ações com características em comum - o que nos levou à evidenciação das sete categorias de ações.

Ao fragmentarmos tais unidades de contexto, passamos a identificar o verbo (transcrito no infinitivo, posicionamento linguístico tomado por nós desde o início da constituição do corpus) que indicava o que os alunos faziam, relacionado diretamente a uma forma de agir, a uma ação. Como indicado, anteriormente, esses movimentos organizacionais e interpretativos fazem parte da primeira etapa dos procedimentos da ATD.

Diante desses resultados, passamos então ao processo de categorização reunindo todas essas formas de agir similares e organizando-as em grupos, o que culminou nas categorias emergentes descritas a seguir na Figura 2. 


\begin{tabular}{|c|c|}
\hline Categorias & Descrições \\
\hline $\begin{array}{l}\text { Categoria 1: } \\
\text { Organiza }(\mathrm{O})\end{array}$ & $\begin{array}{l}\text { As ações alocadas nesta categoria são de dois tipos: as ações burocráticas e as ações } \\
\text { normativas. São exemplos de ações burocráticas: inscrever-se em projetos, responder } \\
\text { a chamadas; as ações próprias dos representantes de turma, como repassar avisos, } \\
\text { organizar reuniões de discussão e realizar a chamada para o controle dos assistentes } \\
\text { de alunos. As ações normativas são aquelas associadas às normas da Instituição e ao } \\
\text { contrato didático realizado entre professor e alunos, tais como: ficar no Instituto, chegar } \\
\text { no horário, cumprir as atividades propostas pela professora, permanecer sentados, usar } \\
\text { uniforme, ficar em silêncio durante a explanação da professora. Esta (sub)categoria } \\
\text { ainda compreende as ações de organização da sala de aula e das atividades realizadas } \\
\text { durante a aula, como, ajudar a professora na entrega de material para a turma, fechar } \\
\text { ou abrir portas e janelas, organizar o material na carteira, colar as listas de exercícios } \\
\text { no caderno, entre outros. Vale ressaltar que ações que vão contra a organização, as } \\
\text { normas e os procedimentos, ou que refletem omissão aos mesmos, estão alocadas } \\
\text { em outra categoria (Dispersa). Existem algumas ações com essas características de } \\
\text { contrariedade que se enquadram como ações de organização, tais como: demorar a } \\
\text { entrar na sala, não realizar a atividade, não voltar do intervalo. }\end{array}$ \\
\hline $\begin{array}{l}\text { Categoria 2: } \\
\text { Interage com } \\
\text { a Professora } \\
\text { (IP) }\end{array}$ & $\begin{array}{l}\text { Nesta categoria foram incluídas as ações de interação entre professor e alunos } \\
\text { diretamente relacionadas ao ensino e à aprendizagem, tais como: prestar atenção na } \\
\text { explanação da professora, perguntar, responder às perguntas da professora, pedir } \\
\text { ajuda etc. Estas ações de interação com a professora tiveram origem ora no aluno ora } \\
\text { na professora. Por exemplo, atribui-se a origem dessas ações ao aluno quando este } \\
\text { fazia comentários e reflexões sobre o assunto, sugeria assuntos de interesse para a } \\
\text { professora, argumentava e insistia em suas opiniões durante as discussões. Quando o } \\
\text { aluno respondia às questões colocadas pela professora, a ação dele foi colocada como } \\
\text { vinculada à ação perguntar, previamente realizada pela professora. }\end{array}$ \\
\hline $\begin{array}{l}\text { Categoria 3: } \\
\text { Interage com } \\
\text { os Colegas } \\
\text { (IC) }\end{array}$ & $\begin{array}{l}\text { Esta categoria refere-se às interações entre dois ou mais alunos, também relacionadas à } \\
\text { aprendizagem e ao ensino. Foram observados dois tipos, que denominamos interações } \\
\text { colaborativas ou de ensino. Nas interações colaborativas os alunos apresentavam o } \\
\text { mesmo nível de conhecimento sobre o assunto eles trabalhavam e desenvolviam o } \\
\text { processo de aprendizagem, juntamente. Quando os alunos apresentavam alguma } \\
\text { diferença quanto ao nível de entendimento do conceito abordado na aula, quem tinha } \\
\text { maior conhecimento assumia o posto de instrutor, configurando a interação como } \\
\text { de ensino. Em meio às interações ocorridas na sala de aula entre os estudantes, as } \\
\text { ações que indicavam colaboração para aprender eram: discutir, traçar caminhos e } \\
\text { estratégias de resolução para os problemas, levantar hipóteses. No caso das interações } \\
\text { que indicavam ensino, havia as ações em que os estudantes assumiam o papel de } \\
\text { aprendizes tais como buscar ajuda do colega, fazer perguntas e aprender com o outro. } \\
\text { De maneira correspondente, havia os alunos que assumiam temporariamente o papel } \\
\text { de professor. Conforme o assunto abordado em sala, estes realizavam ações como: } \\
\text { ensinar o colega, explicar o conteúdo, confirmar o raciocínio dos colegas e corrigir } \\
\text { suas resoluções. }\end{array}$ \\
\hline
\end{tabular}

Figura 2. Descrição das categorias emergentes de ações discentes (continua)

Fonte: os Autores 


\begin{tabular}{|c|c|}
\hline Categorias & Descrições \\
\hline $\begin{array}{l}\text { Categoria } 4: \\
\text { Pratica (P) }\end{array}$ & $\begin{array}{l}\text { A presente categoria representa as ações que os alunos desenvolveram que poderiam } \\
\text { ser caracterizadas como ações diretas de aprendizagem, tais como: participar de } \\
\text { projetos de pesquisas e extensão, estudar, pesquisar, fazer as tarefas, as quais podem } \\
\text { ocorrer tanto dentro da sala de aula, como fora dela, na escola ou em outros ambientes. } \\
\text { As ações típicas de sala de aula podiam ter uma característica mecânica, como copiar } \\
\text { do quadro, apagar, corrigir. No entanto, há ações que envolviam mais reflexão e } \\
\text { raciocínio, como: resolver ou tentar resolver o exercício, fazer associações, pensar, } \\
\text { errar e perceber o erro. }\end{array}$ \\
\hline $\begin{array}{l}\text { Categoria } 5: \\
\text { Espera }(\mathrm{E})\end{array}$ & $\begin{array}{l}\text { Nesta categoria alocamos ações que indicavam a espera do aluno na sala de aula. } \\
\text { Esperar a professora chegar, esperar a professora iniciar a explicação, esperar a } \\
\text { professora retornar à sala, esperar os colegas copiarem, esperar permissão para irem } \\
\text { embora ao término da aula, entre outras. É importante destacar que apenas as ações } \\
\text { puramente de espera foram alocadas nessa categoria, ou seja, quando o aluno não } \\
\text { realizava nenhuma outra ação além de esperar. O período de espera muitas vezes } \\
\text { foi ocupado por outras açôes, quando isso ocorria, elas eram alocadas nas demais } \\
\text { categorias. Conversar, estudar ou realizar trabalhos para outra disciplina, tirar dúvida } \\
\text { com a professora, são alguns exemplos de como eles preenchiam ou aproveitavam o } \\
\text { tempo de espera. }\end{array}$ \\
\hline $\begin{array}{l}\text { Categoria 6: } \\
\text { Dispersa (D) }\end{array}$ & $\begin{array}{l}\text { Essa categoria compreende as ações que ocorreram na sala de aula e que não tinham } \\
\text { qualquer relação com a aprendizagem ou com a aula em si. A ação era desenvolvida } \\
\text { tanto pelos alunos quanto pela professora, na interação entre os sujeitos na sala de aula. } \\
\text { A maioria dessas ações desviava a atenção do aluno e atrapalhava sua aprendizagem. } \\
\text { Por exemplo, manipular o celular, jogar papel nos colegas, trocar mensagens de papel, } \\
\text { brigar, provocar, conversar. Uma variedade de ações dispersivas ocorria no momento } \\
\text { que os alunos chegavam à sala. Cantar, bater palmas, fazer coreografias, assoviar, } \\
\text { gesticular para as câmeras, são ações comuns no início da aula. Há ainda ações que } \\
\text { permitiam a descontração da aula. Colaborar ou atrapalhar no envolvimento com a } \\
\text { aprendizagem, nesse caso, dependia da intensidade da ação. Alguns exemplos para } \\
\text { ilustrar essas situações são: brincar com o colega ou com a professora, comentar sobre } \\
\text { alguma situação com a professora, rir, interromper a atividade, maliciar os temas } \\
\text { abordados pela professora, entre outros. }\end{array}$ \\
\hline $\begin{array}{l}\text { Categoria 7: } \\
\text { Outras Ações } \\
(\mathrm{OA})\end{array}$ & $\begin{array}{l}\text { Essa categoria foi criada para alocar as ações que não se encaixavam em nenhuma } \\
\text { categoria anterior. }\end{array}$ \\
\hline
\end{tabular}

Figura 2. Descrição das categorias emergentes de ações discentes (continuação)

Fonte: os Autores

Realizada a apresentação das categorias, a seguir descrevemos a categorização das ações desempenhadas pelos alunos, para as seis aulas escolhidas para a análise (duas de cada disciplina). Este movimento possibilitou a elaboração das interpretações do fenômeno investigado. Com a categorização das ações observadas no campo de pesquisa foi possível explorar outros aspectos revelados pelas ações discentes, entre eles: as categorias que possuem maior ou menor representatividade para cada disciplina; as ações em comum para essas disciplinas. As diferentes leituras do fenômeno aqui 
apresentadas caracterizam a captação do novo emergente, uma vez que se busca expressar as compreensões atingidas ao longo do desenvolvimento da investigação.

Para melhor conduzir a elaboração do texto deste artigo, a partir deste momento passamos a considerar que a forma de agir dos alunos pode ser representada por verbos ou um conjunto de verbos, como será devidamente esclarecido a seguir e que denominaremos por 'ações', simplesmente.

\section{As Aulas Analisadas e Suas Categorias de Ações}

Antes de relacionar as ações relativas às duas aulas de cada disciplina, esclareceremos alguns posicionamentos que tomamos em relação à redação dos verbos.

A princípio as ações foram escritas com o verbo no infinitivo e, ao serem classificados de acordo com as categorias de ações, notou-se que em algumas delas o verbo empregado durante o registro não representava a ação em sua especificidade. Por esse motivo, houve casos em que essas ações foram representadas por dois verbos, constituindo uma única unidade de contexto. O primeiro é o que foi empregado na frase nas notas de campo e o segundo é o que realmente foi feito pelo aluno, no momento da visualização e transcrição do vídeo gravado durante as aulas.

Para ilustrar tal situação, trazemos um exemplo: na nota de campo temos a anotação, "dizer" para representar o seguinte registro “[...] A24 diz que: Divisão por zero não existe porque a calculadora deu erro", todavia, ao observarmos a gravação em vídeo checamos que o verbo dizer não representava integralmente o que havia ocorrido, pois o aluno disse em resposta a uma pergunta da professora, isto é, disse respondendo, por isso a complementação necessária - Dizer: Responder.

$\mathrm{Na}$ Tabela 1, nas colunas 2, 3 e 4, temos o percentual de verbos relacionados, respectivamente, as disciplinas de Matemática, Física e Química, para cada uma das categorias de ações discentes mostrada na coluna 1.

Tabela 1. Categorias de ações e os percentuais de unidades de contexto para cada disciplina

\begin{tabular}{lccc}
\hline Categorias de ações & Matemática & Física & Química \\
\hline Organiza (O) & $28,38 \%$ & $23,53 \%$ & $36,23 \%$ \\
Interage com a Professora (IP) & $22,97 \%$ & $23,53 \%$ & $20,29 \%$ \\
Interage com os Colegas (IC) & $6,76 \%$ & $7,35 \%$ & $1,45 \%$ \\
Pratica (P) & $10,81 \%$ & $10,29 \%$ & $7,25 \%$ \\
Espera (E) & $1,35 \%$ & $1,47 \%$ & $1,45 \%$ \\
Dispersa (D) & $28,38 \%$ & $33,82 \%$ & $33,33 \%$ \\
Outras Ações (OA) & $1,35 \%$ & $0 \%$ & $0 \%$ \\
\hline Total Geral & 74 ações - $100 \%$ & 68 ações - $100 \%$ & 69 ações $-100 \%$ \\
\hline
\end{tabular}

Fonte: os Autores

Destacamos que foram evidenciados 74 verbos ou conjunto de verbos que representam nossas unidades de contexto para as aulas da disciplina de Matemática; 68 
para as aulas de Física; 69 para as de Química. Esses valores percentuais representam quantitativamente a intensidade de unidades de contexto para cada categoria, isto é, $28,38 \%$ do que representa as ações dos estudantes, está alocada na categoria Organiza, nas duas aulas de Matemática, enquanto que nas aulas de Física esta categoria de ação acomodou um percentual de 23,53\% e nas de Química 36,23\%.

A categoria Outras Ações só foi contemplada na disciplina de Matemática, com uma única ação representante. A categoria Espera foi a que alocou o menor número de ações para as três disciplinas, representada pelo verbo Aguardar. A maior quantidade de ações inventariadas pertence às categorias Organiza e Dispersa. Essas duas categorias, em todas as disciplinas, apareceram com uma percentagem maior. Isso, porque são aquelas que acomodam a maior quantidade de verbos ou conjunto de verbos que descrevem as unidades de contexto ocorridas nas aulas. Essa maior quantidade deve-se à natureza diversificada dessas duas categorias que apresentam uma maior gama de ações que as representam em diversos contextos.

A categoria Interage com a Professora foi a terceira categoria com maior incidência de ações, seguidas das categorias Pratica e Interage com os Colegas. Estas três categorias são as que, para nós, manifestam relações diretas com a aprendizagem. Analisando as duas categorias de interação, na perspectiva de Illeris (2013), os alunos utilizam-se de ações próprias do processo de interação para aprender. Sob o olhar de Charlot (2000), e em conformidade com Illeris, os discentes se valem da relação com o outro com o intuito de adquirir um saber.

A categoria Pratica pode ser entendida como as ações que os alunos realizam para aprender. $\mathrm{Na}$ teoria abrangente de aprendizagem proposta por Illeris (2013) esta categoria envolve, principalmente, o processo psicológico interno, envolvendo as dimensões de conteúdo e incentivo para a aprendizagem deste. De acordo com a Teoria da Relação com o Saber de Charlot (2000) esta categoria está associada às ações que compõem uma atividade intelectual na intenção de aprender um conteúdo.

Como comentado anteriormente, a 'dinâmica' da sala de aula, para cada uma das disciplinas, foi diferente, principalmente, quando consideramos a singularidade de cada professora, contudo os percentuais que representam a forma de agir dos estudantes foram similares. Nesse sentido, para melhor entender as diversas nuances a respeito do que se passou nessas aulas analisadas, quando focamos naquilo que os alunos realmente fazem, damos continuidade à nossa proposição de apresentar outras formas de acomodar essas informações. Com isso, buscamos evidenciar as unidades de contexto em comum para as três disciplinas por categoria de ação, assim como as ações que ocorreram especificamente na aula de cada disciplina. Para tal elaboramos cinco diagramas de Venn, desconsiderando as categorias Espera (por ter uma incidência percentual muito pequena) e Outras Ações (por ter sido evidenciada somente para a disciplina de Matemática). Os diagramas seguem a ordem em que as categorias de ação foram organizadas na Figura 2.

A codificação utilizada para os verbos ou conjunto de verbos seguiu-se o seguinte 
critério: a primeira letra está relacionada à disciplina $\mathrm{M}$ para Matemática, $\mathrm{F}$ para Física e Q para Química; a segunda (e terceira) letra(s) representa $(\mathrm{m})$ a codificação de cada uma das sete categorias emergentes apresentadas na Figura 2, por exemplo, Organiza foi codificada por O; por fim, depois das duas letras temos um número, que representa a posição daquele verbo ou conjunto de verbos na lista de ações, organizada em ordem alfabética. Sendo assim, MO1 refere-se à primeira ação da categoria $\mathrm{O}$ para duas aulas analisadas de Matemática.

$\mathrm{Na}$ Figura 3, temos o primeiro diagrama relativo à categoria Organiza $(\mathrm{O}) . \mathrm{Na}$ região central foram acomodadas as unidades de contexto - descritas por meio de verbos ou conjunto de verbos - que se fizeram presentes nas aulas das três disciplinas, omitindo parcialmente os códigos que agora mantiveram apenas a numeração correspondente devido a otimização do espaço, na sequência Matemática, Física e Química. Nas demais regiões a codificação foi mantida como descrito acima.

Essa forma de representação e organização dos dados permite-nos diversas leituras que trazem detalhes sobre o que de fato aconteceu nestas salas de aula, no que diz respeito ao que os alunos faziam. Teceremos diversos comentários, contudo sabemos que outras argumentações seriam possíveis.

A categoria $\mathrm{O}$ para a aula de Matemática compreende ações preparatórias para o início e encerramento de aula (MO1 - Chegar e MO17 - Sair da sala); ações para a manutenção da ordem na sala (MO8); a respeito da elaboração de acordos didáticos e ao (des)cumprimento de normas estabelecidas, seja pela escola ou pelos acordos feitos com a professora (MO3, MO19 e MO20); e ações de organização em geral (MO11). Essas são ações que comumente acontecem nas demais disciplinas, sendo apresentadas apenas com a codificação específica à cada uma delas. No entanto, o diagrama nos revela, agilmente, ocorrências específicas nas aulas de Matemática, como: ações de organização da sala de aula (MO7 e MO13), do material instrucional (MO2 e MO15) e do tempo de aula (MO18).

A categoria $\mathrm{O}$ para a aula de Física, além das ações comuns as demais disciplinas, houve também ações de interação com a professora no âmbito organizacional. PF em conjunto com os discentes organizaram o modo como seriam repassadas as listas de exercícios (FO13) e debateram a respeito do uso de calculadora e do celular em sala de aula (FO5, FO12, FO14).

O círculo representativo da aula de Química apresenta ações em todas as regiões que o compõem. Na região em comum entre Matemática e Química, ressalta-se o fluxo de alunos durante a aula (QO23 e QO24). Já a região entre Química e Física (QO1, QO6 e QO25), refere-se às ações comuns ao momento inicial das aulas. As ações de organização que aconteceram exclusivamente em Química surgiram da necessidade: de os alunos melhor visualizarem as informações dos slides (QO15 e QO11); de tempo para anotações no caderno (QO17); de organização da sala e dos materiais escolares (QO8, QO10, QO16, QO20 e QO21). 


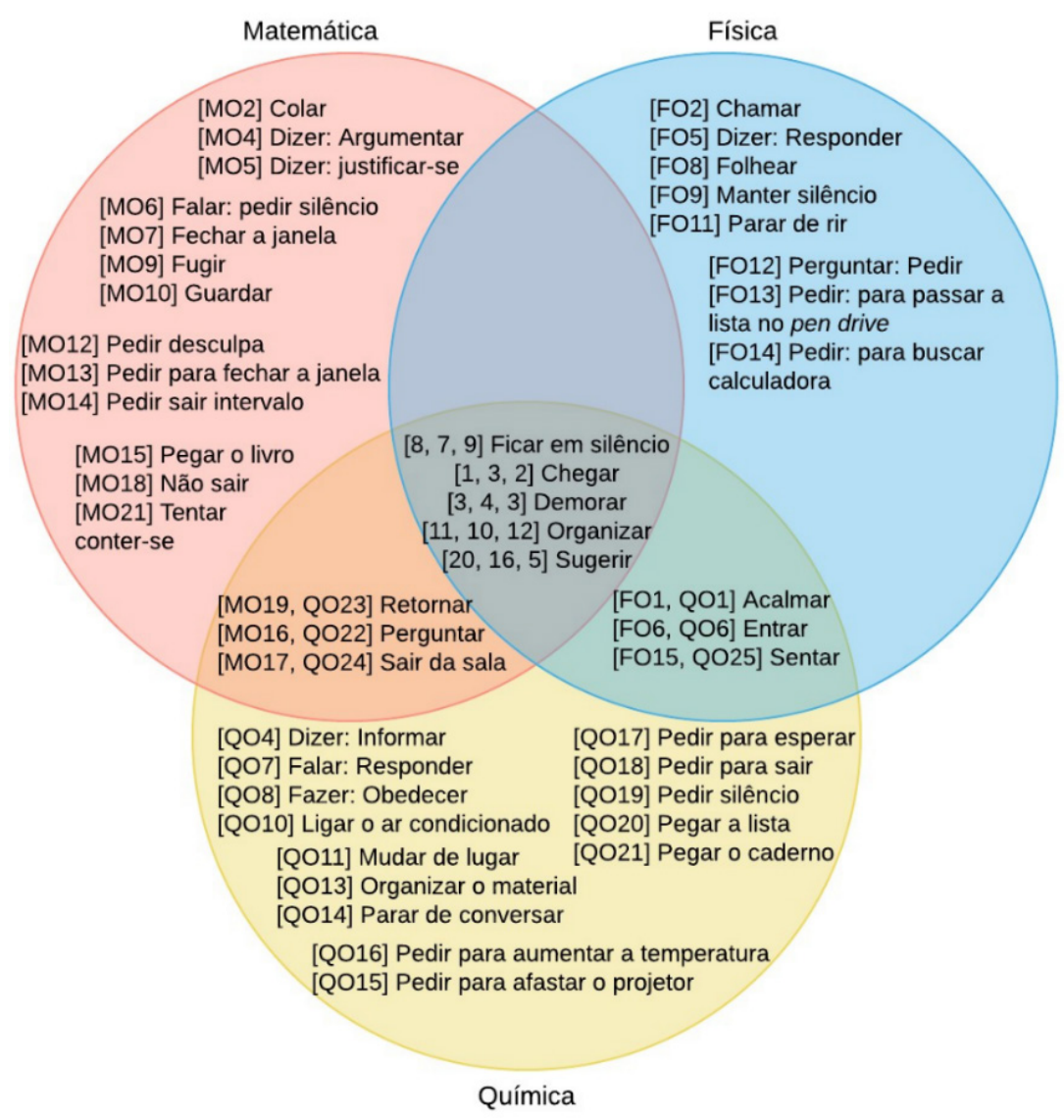

Figura 3. Diagrama da categoria de ação Organiza

Fonte: os Autores

$\mathrm{Na}$ Figura 4 acomodamos as informações sistematizadas a respeito da categoria IP e pode-se observar que todas as regiões do diagrama foram contempladas. E as ações de Interação com a Professora que ocorreram nas três disciplinas foram: tecer reflexões a respeito do conteúdo - Dizer: Refletir; Perguntar; Prestar atenção; Responder.

A região comum entre Matemática e Química, apresentaram ações discentes tais como: comentários em concordância com a fala da professora e suas explicações (MIP4 e QIP6); e exposição das dúvidas quanto ao conteúdo (MIP17 e QIP6). Com relação à intersecção entre Matemática e Física, destacamos as ações: MIP12 e FIP10 referente as omissões quanto as perguntas realizadas pelas docentes; e MIP13 e FIP13 que caracterizavam pedidos de auxílio às professoras para a resolução dos exercícios. Especificamente na aula de Matemática, os alunos se envolviam (MIP7), opinavam (MIP5) e insistiam em seus posicionamentos (MIP8) durante as discussões. E o modo encontrado pelos discentes para esclarecer as dúvidas quanto ao conteúdo foi de explicar para a professora como eles solucionaram os exercícios (MIP2). 


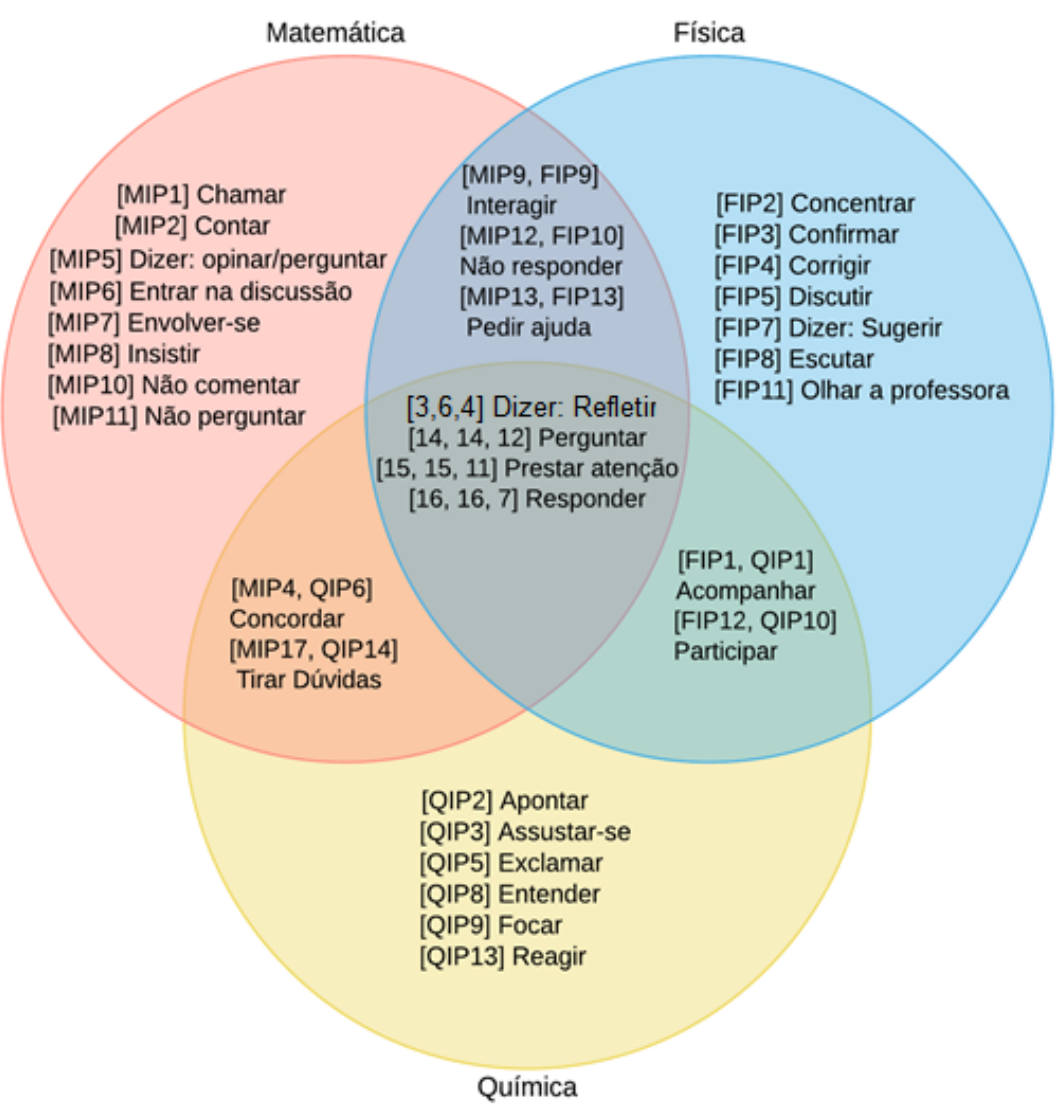

Figura 4. Diagrama da categoria de ação Interage com a Professora

Fonte: os Autores

A intersecção das ações da aula de Física com Química para a categoria IP contém ações que indicam que os alunos acompanhavam as explicações, orientações e correções das professoras (FIP1 e QIP1) e que participavam das interações entre professoras e alunos (FIP12 e QIP10). Destacaram-se como ocorrências próprias da aula de Física as ações de correção durante as discussões. Como a professora conduzia a explicação do conteúdo por meio de perguntas, os alunos cometiam erros, PF comunicava aos alunos o erro cometido, e eles retomavam o assunto reelaborando o processo, corrigindo a manifestação (FIP4). Conversas sobre o conteúdo (FIP3 e FIP8) e sugestões de assuntos de interesse para serem abordados na aula de Física (FIP7), também puderam ser observadas.

Para a aula de Química a categoria IP apresentou a menor representação entre as três disciplinas. As ações particulares a aula de Química, apresentam-se as reações dos alunos diante da nomenclatura das Cadeias Carbônicas. Nesse sentido, os alunos reagiram com surpresa (QIP3) e proferiram exclamações de espanto (QIP5). Eles também apresentaram reações de entusiasmo (QIP13) quando conseguiam entender uma dúvida.

Na sequência, na Figura 5, temos o diagrama que traz informações relativas à 
categoria IC, como fica evidente, em um rápido olhar, o número de ações para essa categoria foi pequeno, quando comparamos com as categorias comentadas anteriormente e com as incidências nas três disciplinas consideradas. Apesar de os alunos terem interagido de forma contínua em muitos momentos da aula, as interações que poderiam ter promovido a aprendizagem do conteúdo foram poucas, destacando que nessas duas categorias, que tomamos as interações com as professoras e com os colegas, nossas considerações estavam voltadas para os processos de aprendizagem que tais interações poderiam proporcionar.

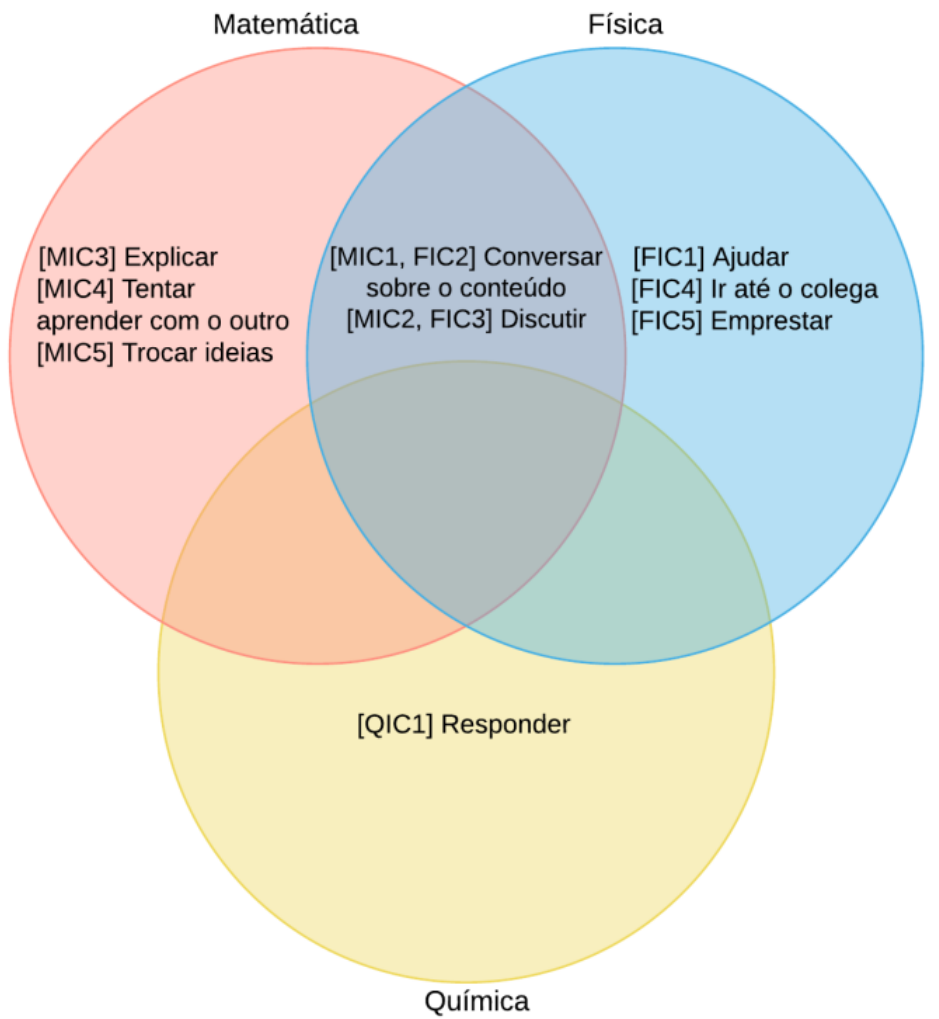

Figura 5. Diagrama da categoria de ação Interage com os Colegas

Fonte: os Autores

A categoria IC para a aula de Matemática é constituída apenas por cinco ações e duas delas são comuns à aula de Física. Estas últimas foram ações em que os alunos conversaram a respeito do conteúdo (MIC1 e FIC2) e discutiram sobre os exercícios (MIC2 e FIC3). As demais interações de aprendizagem entre os colegas de classe (MIC3 - Explicar, MIC5 - Tentar aprender com o outro e MIC4 - Trocar ideias) ocorreram principalmente nos momentos da aula de Matemática destinados à resolução de exemplos e exercícios.

A aula de Física também apresentou cinco ações para a categoria IC, apesar de PF ter destinado um período maior da aula para a realização de exercícios em comparação as demais disciplinas. Observamos que o emprego de maior tempo não motivou ampla 
variedade de ações para esta categoria, porém notamos que houve aumento na frequência em que elas ocorreram. Propriamente na aula de Física houve maior colaboração entre os alunos, eles escolhiam se formariam grupos, ou se tentariam resolver a atividade sozinhos. Alguns deles circulavam pela sala (FIC4), ensinando os colegas nas resoluções (FIC1), ou buscando auxílio para aprender (FIC5).

A categoria IC para a aula de Química apresentou a menor quantidade de ações em comparação com os dois outros conjuntos de aulas analisados. Esta categoria foi contemplada com apenas a ação de Responder (QIC1), em que um aluno respondeu à pergunta de outro, que havia sido direcionada para a professora. Ponderamos que um dos motivos para essa baixa ocorrência de Interação com os Colegas tenha sido a ausência de momentos para a resolução de exercício nas aulas de Química analisadas.

Vale salientar, que para além dos momentos destinados aos exercícios nas referidas aulas, os quais potencializavam a ocorrência de ações de interação de aprendizagem com os colegas, a forma como as professoras conduziram suas aulas, também é um fator a ser considerado. As aulas em análise, todas foram ministradas pelas professoras de forma expositiva. PM e PQ desenvolveram poucos momentos de discussão a respeito dos conteúdos abordados. As perguntas realizadas por elas ocorriam mais no sentido de confirmar o entendimento dos alunos em relação à explicação. As discussões que surgiram foram pouco exploradas ou ficaram no nível de interação entre aluno e professor. PF fomentou as interações entre os colegas de turma sobre os assuntos da aula, gerando maior ocorrência de discussões.

No próximo diagrama - Figura 6 - dedicamo-nos à categoria Pratica presente nas aulas analisadas. Semelhantemente à categoria anterior ela trouxe, segundo nossos critérios analíticos, pouca variedade de ações, ou seja, daquilo que pudemos descrever a respeito da atuação dos alunos em sala de aula.

O que eles praticaram comumente nas três disciplinas foi copiar o conteúdo ou as resoluções de exemplos e exercícios da lousa. Como pode ser verificado no diagrama, não houve ações comuns na região de intersecção para as disciplinas de Matemática e Química.

As ações alocadas na categoria $\mathrm{P}$ estão associadas ao momento da aula em que elas ocorreram. No início da aula de Matemática, durante o momento de espera pelos demais alunos, os presentes aproveitavam o tempo para estudar (MP2). No período destinado aos exercícios, os alunos realizavam ações como: iniciar a atividade (MP3) e resolver os exercícios (MP8), ação também ocorrida na aula de Física (FP7). As omissões não copiar (MP4), não mostrar interesse (MP6), não se esforçar (MP5), caracterizavam o modo como alguns alunos enfrentavam a aula de Matemática.

As ações da categoria P, para a aula de Física, estão principalmente ligadas aos períodos de correção e resolução de exercícios. Durante a correção a ação prática do aluno foi de corrigir (FP2 e QP1), fato que ocorreu também em Química. As ações exclusivas da aula de Física foram o enfrentamento das dificuldades (FP3) e ações com viés reflexivo como: errar (FP4); pensar (FP5) e perceber o erro (FP6). As ações FP4 e 
FP2 revelam ainda a liberdade sentida pelo aluno em correr riscos nas discussões da aula.

Apesar da ausência do momento de resolução de exercícios na aula de Química, a categoria $\mathrm{P}$ não sofreu grande variação em relação ao valor percentual das demais aulas observadas. Especificamente para a aula de Química as ações discentes foram: anotar em seus cadernos seguindo a orientação de PQ as informações destacadas por ela (QP2); associar os assuntos abordados na aula com conceitos já conhecidos (QP5) e por fim, tem-se o comentário de um aluno para a pesquisadora (QP4), a respeito da nomenclatura de um exemplo usado pela professora.

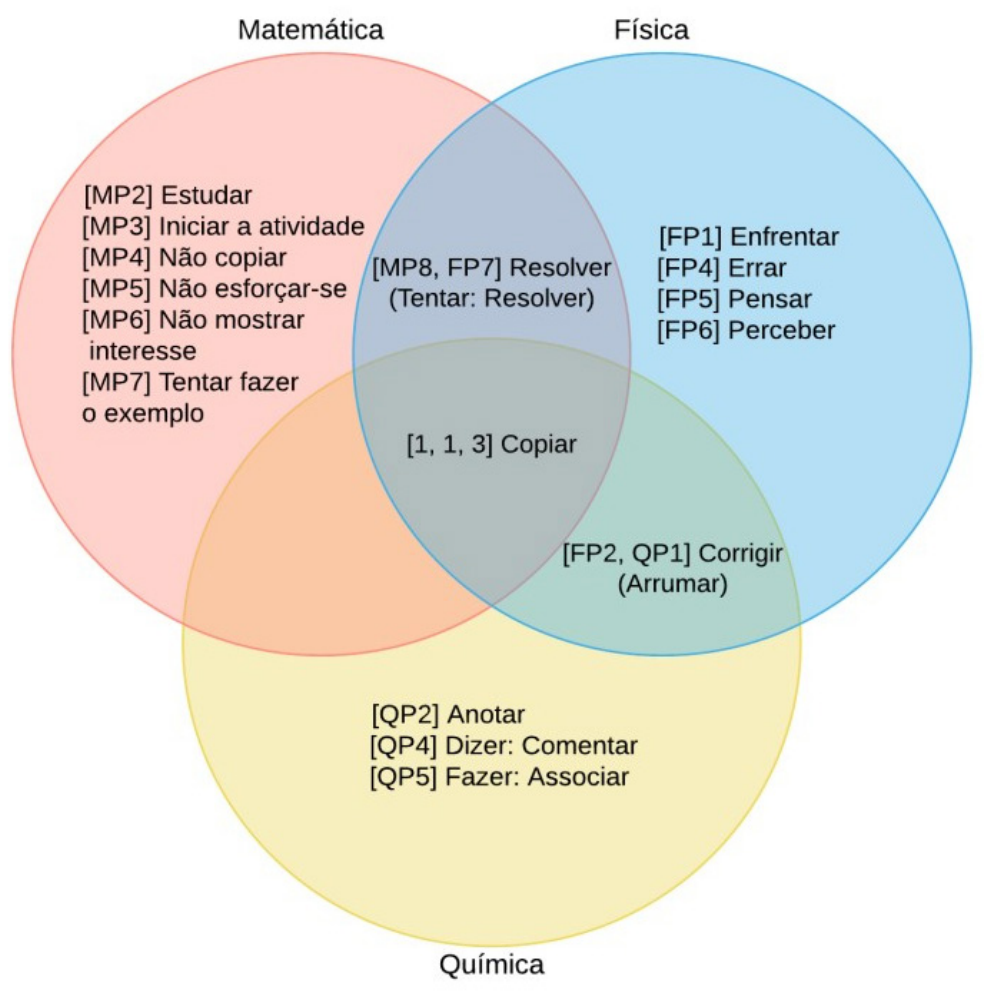

Figura 6. Diagrama da categoria de ação Pratica

Fonte: os Autores

Na Figura 7 inserimos as informações relativas à categoria Dispersa. Como já indicado, foi a categoria com maior variedade de unidades de registro, ou seja, aquela que comportou, segundo nossas descrições, aquilo que os alunos faziam, a maior quantidade de verbos ou de conjuntos de verbos representativos dos fazeres desses alunos. Uma leitura ágil do que temos descrito no diagrama mostra essa diversidade. Destacamos neste parágrafo somente aquelas que compõem a tripla interseção: Brincar; Conversar; Gesticular; Manipular o celular; Mostrar algo no celular; Rir. 


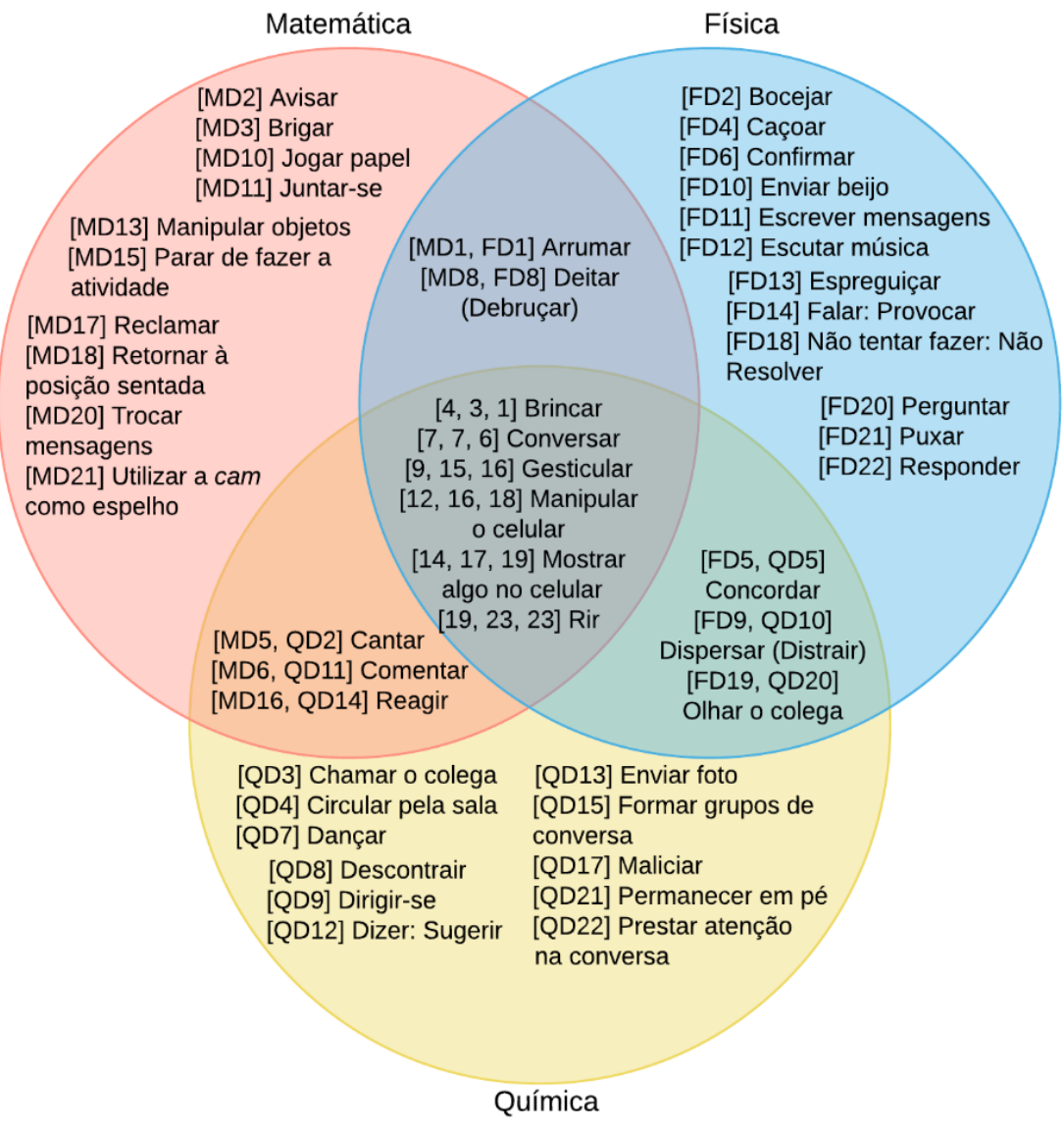

Figura 7. Diagrama da categoria de ação Dispersa

Fonte: os Autores

A sala de aula, por ser um ambiente social, as trocas realizadas pelos participantes não se referem apenas ao conteúdo da disciplina, mas extrapolam os assuntos curriculares. O início da aula é um dos períodos em que as interações sociais ocorreram com um número maior de ações. Na aula de Matemática e Química os alunos chegavam à sala animados, cantavam (MD5 e QD2), comentavam os assuntos do dia (MD6 e QD11). No decorrer da aula de Matemática e Física, alguns dos alunos que não manifestavam interesse no que era abordado, tornavam-se sonolentos (MD8, FD8 e MD18). O uso do celular foi uma ação recorrente em todas as aulas, mesmo que, especificamente em Matemática, tenha sido proibido utilizá-lo. Essa proibição promoveu maior variabilidade dos meios de comunicação (MD7 - conversar, MD12 - manipular o celular, MD20 - trocar mensagens de papel e MD9 - gesticular). Os alunos encontravam meios de distração, como interagir com os materiais escolares (MD13 e MD10) e com os materiais de coleta da pesquisadora (MD21). Ocorreram também ações que indicavam insatisfação de alguns alunos em relação a alguns momentos da aula (MD17).

Para a aula de Física as ações foram semelhantes às que ocorreram em Matemática, o que diferiu foi o uso do celular. $\mathrm{Na}$ aula de Física a professora permitiu o uso do 
aparelho, principalmente pelo compartilhamento das listas de exercícios. No entanto, a permissão acarretou outras ações de natureza dispersiva: escutar músicas (FD12); envio de mensagens (FD16 e FD17); acesso a redes sociais (FD11). As ações discentes dispersivas comuns à Física e à Química foram as ações de: concordar (FD5 e QD5) com a professora sobre assuntos que não diziam respeito ao conteúdo; distrair (FD9 e QD10) e observar os colegas (FD19 e QD20). A interação da professora com os alunos também se tornou fonte geradora de ações de dispersão. Neste caso os alunos interagiam com a professora abordando assuntos pessoais (FD20), eventos (FD6), filmes e séries (FD22) e brincavam e faziam piadas (FD4 e FD14).

Encerrando tais apresentações, na forma de diagrama, destacamos que as ações da categoria D - Dispersa - para Química. Grande parte das ações dispersivas ocorreu no momento inicial, quando os alunos demoraram a se organizar para a aula. Assim como em Física, nesta aula foi permitido o uso do celular, gerando situações dispersivas (QD13 - Enviar fotos). A ação QD17 ilustra uma situação diferente das demais aulas, em que os alunos maliciaram ao perceberem os nomes dados para as diferentes cadeias que representavam os alcanos. Os alunos buscavam descontrair (QD8), sem que com isso atrapalhassem o desenvolvimento da aula ou atraíssem a atenção da professora para eles.

\section{Considerações Evidenciadas}

Inspirados pelo que Charlot (2005) nos apresenta, associando a aprendizagem a uma prática do saber, entendida como ações contextualizadas e direcionadas, cujas finalidades são a de adquirir um saber, adentramos em um movimento investigativo a fim de acompanhar o cotidiano de uma turma em sala de aula e com a intenção de responder à seguinte questão: Quais são as categorias de ações discentes em aulas de Física, Matemática e Química?

Esse contato direto com os alunos em sala de aula possibilitou a observação do que eles faziam, culminando em uma vasta listagem de ações, que para nós retratava esse fazer. Diante de tais constatações e da retomada das gravações em vídeo de todas as aulas de Física, Matemática e Química, durante um bimestre, foi possível elaborar sete categorias de ações emergentes, em que a vasta listagem pode ser acomodada, segundo os procedimentos da ATD.

Diante desse estudo realizado somos levados a concluir que essas sete categorias revelam diferentes aspectos da experiência discente vivenciada no contexto investigado e que podem ser representadas pelas seguintes palavras ou expressões: Organiza, Interage com a Professora, Interage com os Colegas, Pratica, Espera, Dispersa e Outras Ações, cada qual com suas caracterizações próprias.

Foi possível evidenciar que as categorias Organiza, Espera, Dispersa e Outras Ações, compreende ações discentes que não estão necessariamente voltadas para a aprendizagem. A maioria delas são ações que permeiam o cotidiano escolar fruto das demais relações construídas em sala de aula. Nestas ações vislumbramos com mais 
intensidade os fazeres em função das diretrizes e normas institucionais, dos acordos didáticos, dos modos de organização da sala de aula, da socialização entre os participantes, o que, a nosso ver, não está diretamente relacionado com os momentos de aprendizagem de um saber científico, contudo podem interferir de forma positiva ou negativa para tal. Já as categorias Interage com a Professora, Interage com os Colegas e Pratica consistem em ações que estão diretamente ligadas ao aprender em sala de aula, representando os momentos em que os alunos agiam em função da própria aprendizagem. Descrevemos, resumidamente, nesta conclusão do artigo, cada uma dessas categorias, exceto Outras Ações (que ocorreu uma única vez).

$\mathrm{Na}$ categoria Organiza $(\mathrm{O})$ acomodamos as ações relativas às normas da Instituição de Ensino, aos acordos e contratos didáticos entre professor e alunos, as ações burocráticas e a organização e manutenção da ordem na sala de aula.

$\mathrm{Na}$ categoria Espera (E) inserimos as ações em que o aluno permanecia inativo, aguardando a finalização, o início, ou a retomada de ações pelos colegas ou pela professora.

$\mathrm{Na}$ categoria Dispersa (D) foram agrupadas as ações que apresentavam um potencial para desviar a atenção dos alunos, da atividade principal proposta nos momentos da aula, afastando-os dos processos de ensino e de aprendizagem.

Em consonância com as ideias de Charlot (2000), as duas primeiras categorias descritas acima não caracterizam um aprender de um conteúdo, mas sim um aprendizado de atitudes e relações que poderiam potencializar a aprendizagem de um saber específico em sala de aula. Já a terceira categoria, pode ser associada a aprendizagem relacional, sendo possível colaborar ou prejudicar a aprendizagem de um saber científico. No entanto as ações dessa categoria indicam que o ambiente escolar é um ambiente fecundo para a formação do estudante, não apenas no sentido científico, mas para uma aprendizagem ampla que compreende variados aspectos da formação humana.

Nas categorias Interage com a Professora (IP) e Interage com os Colegas (IC), incluímos as ações que promoviam a aprendizagem mediante as interações com o outro, seja ele a professora ou um colega de sala, e sempre estavam permeadas por um processo formativo e colaborativo.

As ações dessas duas categorias podem ser associadas à dimensão de interação do modelo de aprendizagem proposto por Illeris (2013). Neste caso, os alunos utilizam-se da interação com o meio externo para aprender. Pensando o aprender como uma prática do saber, conforme Charlot (2005), as ações das categorias IP e IC estão associadas a atividades relacionais e reflexivas. A primeira fomenta a segunda por meio da relação discente com o outro, o que pode contribuir para aprendizagens de conceitos científicos.

Na categoria Pratica $(\mathrm{P})$ temos as ações práticas desenvolvidas em sala de aula e que visavam a aprendizagem dos alunos, entre as quais destacamos: os registros e as anotações relacionadas ao conteúdo; a resolução de exercícios; a realização de experiências; os momentos de pesquisa; a participação das oficinas; a apresentação dos seminários. Tais ações dependiam exclusivamente de cada um dos estudantes, que 
precisavam estar engajados na discussão da aula para realizarem-nas.

A categoria Pratica, sob a perspectiva de Illeris (2013), associa-se a dois processos. O primeiro trata-se do processo de interação, uma vez que esta categoria consiste em ações que envolvem o estudante com o ambiente externo. O segundo refere-se ao processo psicológico interno, englobando as dimensões de conteúdo e de incentivo. Isto porque, a maior parte das ações de prática para a aprendizagem exige do aluno envolvimento, emoção, mobilização, para o desenvolvimento de conhecimentos e habilidades. Frente a teoria de Charlot $(2000,2005)$ esta categoria configura ações para a aquisição de um saber no sentido de um conteúdo intelectual, envolvendo diretamente ações práticas e reflexivas. Estas ações correspondem a um fazer tanto inscrito no corpo (indicando o domínio de objeto ou atividade, como copiar, anotar), quanto um fazer cognitivo (como pensar, refletir, elaborar estratégias).

Um fato que nos chamou a atenção está relacionado à maneira com que cada uma das professoras planeja suas aulas e organiza a sala de aula, e como esse planejamento reflete diretamente naquilo que os alunos fazem, ou seja, em suas ações. Esta ocorrência observada no contexto investigativo vem de encontro com a perspectiva de Weber (2012) e o conceito de ação social, em que o sentido da ação orienta-se pelo comportamento de outros. Trazemos alguns exemplos para elucidar tal afirmação: PM tratava os alunos com mais formalidade que PF e PQ, o que levou à evidenciação de ações relativas a omissões por parte dos alunos, todavia, por outro lado, atendiam, com mais afinco, às propostas feitas pela professora; PF mostrou-se mais amigável aos alunos, fato que fomentou a participação ativa (da maioria deles) nas discussões, promovendo ações reflexivas nos momentos de prática, o que não foi evidenciado nas aulas de Matemática e Química analisadas; PQ planejou suas aulas trazendo somente a exposição de conteúdo e sem a proposição de exercícios para os alunos, o que incidiu em um número menor de ações de práticas e reduziu significativamente a interação de aprendizagem com o colega.

Essa forma de categorização a que nos dedicamos para expor os resultados desta pesquisa traz uma leitura singular do fenômeno investigado, todavia permite concluir que as ações discentes elencadas para as disciplinas analisadas são majoritariamente semelhantes para as três disciplinas ( $\mathrm{O}$, IP e $\mathrm{D}$ tiveram maior ocorrência nas três disciplinas) e o que as diferencia, em resumo, são as maneiras com que as aulas foram planejadas e a sala de aula organizada, características que estão relacionadas ao que faz o professor e não diretamente ao fazer do aluno. Estes fatos nos permitem inferir no contexto das interações entre professor e alunos, em sala de aula, que existe uma correlação entre as ações docentes e discentes. Investigar esses dois distintos grupos de ações, assim como as possíveis correspondências entre eles representa um avanço para as pesquisas da área de Ensino de Ciências. Podemos destacar ainda que a presente investigação contribui para o público docente. Isso porque, ao olhar para o agir do aluno, o professor poderá organizar o seu planejamento, utilizando de estratégias metodológicas que favoreçam o desencadeamento de ações discentes que contribuam para a aprendizagem, que restrinjam ações de caráter dispersivo e que elevem a qualidade 
das relações e das interações no sistema didático.

Por fim, concluímos este artigo com a esperança de que esta investigação possa contribuir com a compreensão do que realmente ocorre em sala de aula quando focamos aquilo que os alunos fazem em sala de aula, evidenciado por suas ações e suas relações com o ensino e a aprendizagem. Pois julgamos que compreender a perspectiva discente nas relações didático-pedagógicas e entender as ações por eles realizadas em sala de aula é uma forma de abrir espaço no campo de pesquisa para dar voz aos estudantes e tornar o processo de ensino e aprendizagem mais humano.

\section{Agradecimentos}

Agradecemos à Fundação Araucária e ao Conselho Nacional de Desenvolvimento Científico e Tecnológico pelo apoio financeiro.

\section{Referências}

Andrade, E. C. (2016). Um estudo das ações de professores de matemática em sala de aula. Tese (Doutorado em Ensino de Ciências e Educação Matemática) - Universidade Estadual de Londrina, Londrina.

Andrade, E. C., Arruda, S. M., \& Passos, M. M. (2018). Descrição da ação docente de professores de Matemática por meio da observação direta da sala de aula. Educação Matemática Pesquisa, 20(2), 349-368. http://dx.doi.org/10.23925/1983-3156.2018v20i2

Arruda, S. M., Benício, M. A., \& Passos, M. M. (2017). Um instrumento para a análise das percepções/ações de estudantes em sala de aula. Revista Brasileira de Ensino de Ciência e Tecnologia, 10(2), 1-21. http://doi.10.3859/rbect.v10n2.4457

Bardin, L. (2011). Análise de conteúdo. 4. ed. Lisboa: Edições 70.

Benicio, M. A. (2018). Um olhar sobre as ações discentes em sala de aula em um IFPR. 300 f. Tese (Doutorado em Ensino de Ciências e Educação Matemática) - Universidade Estadual de Londrina, Londrina.

Carvalho, D. F., Arruda, S. M., \& Passos, M. M. (2018). Um estudo das mudanças das ações docentes de um supervisor do PIBID-Matemática. Zetetiké, 26(2), 318-336. https://doi.org/10.20396/zet.v26i2.8649577

Charlot, B. (2000). Da relação com o saber: elementos para uma teoria. Porto Alegre: Artmed.

Charlot, B. (2005). Relação com o saber, formação dos professores e globalização: questão para a educação hoje. Porto Alegre: Artmed.

Charlot, B. (2013). Da relação com o saber às práticas educativas. São Paulo: Cortez. 
Dias, M. P. (2018). As ações de professores e alunos em salas de aula de matemática: categorizações e possíveis conexões. Dissertação (Mestrado em Ensino de Ciências e Educação Matemática) - Universidade Estadual de Londrina, Londrina.

Dias, M. P., Arruda, S. M., Oliveira, A. C., \& Passos, M. M. (2017). Relações com o ensinar e as categorias de ação do professor de Matemática. Caminhos da Educação Matemática em Revista, 7(2), 66-75.

Gauthier, C., Martineau, S., Desbiens, J. F., Malo, A., \& Simard, D. (2013). Por uma teoria da pedagogia: pesquisas contemporâneas sobre o saber docente. Ijuí: Unijuí,

Illeris, K. (2013). Uma compreensão abrangente da aprendizagem humana. In K. Illeris (Org.), Teorias contemporâneas da aprendizagem (pp. 15-30). Porto Alegre: Penso.

Leontiev, A. N. (1978). O desenvolvimento do psiquismo. Lisboa: Horizonte Universitário.

Leontiev, A. N. (2014). Atividade e Consciência. (M. J. S. Silva, Trad.). Revista Dialectus, 2(4), 184-210. (Obra original publicada em 1972)

Moraes, R., \& Galiazzi, M. C. (2011). Análise textual discursiva. 2. ed. Ijuí: Unijuí.

Schön, D. A. (1992). Formar professores como profissionais reflexivos. In A. Nóvoa (Coord.), Os professores e sua formação (pp. 77-91). Lisboa: Dom Quixote.

Tardif, M. (2014). Saberes docentes e formação profissional. Petrópolis: Vozes.

Weber, M. (2012). Economia e sociedade. Brasília: UNB. 
Marily Aparecida Benicio

${ }^{\circ}$ https://orcid.org/0000-0002-2790-7425 Instituto Federal do Paraná Telêmaco Borba, Paraná, Brasil marily.benicio@ifpr.edu.br

Sergio de Mello Arruda

${ }^{\circ}$ https://orcid.org/0000-0002-4149-2182 Universidade Estadual de Londrina Programa de Pós-Graduação em Ensino de Ciências e Educação Matemática Londrina, Paraná, Brasil sergioarruda@uel.br

\section{Marinez Meneghello Passos}

'ichttps://orcid.org/0000-0001-8856-5521

Universidade Estadual de Londrina Programa de Pós-Graduação em Ensino de Ciências e Educação Matemática Londrina, Paraná, Brasil Universidade Estadual do Norte do Paraná Programa de Pós-Graduação em Ensino Cornélio Procópio, Paraná, Brasil marinezpassos@uel.br

Submetido em 25 de junho de 2019 Aceito em 17 de outubro de 2019 Publicado em 09 de novembro de 2019 